\title{
The relationship of systemic inflammation to prior hospitalization in adult patients with cystic fibrosis
}

\author{
David A Ngan, Pearce G Wilcox, May Aldaabil, Yuexin Li, Jonathon A Leipsic, Don D Sin and SF Paul Man
}

\begin{abstract}
Background: In cystic fibrosis (CF) patients, it has been suggested that systemic inflammation may be an important risk factor for poor health outcomes. The relationship of plasma inflammatory biomarkers to lung function and hospitalization history remains largely unexplored.

Methods: This cross-sectional study included 58 consecutive, clinically stable adults from the CF Clinic at St. Paul's Hospital (Vancouver, Canada). Blood levels of interleukin (IL)-6, IL-1 $\beta$, C-reactive protein (CRP), interleukin (IL)-6, IL$1 \beta$, granzyme B (GzmB), chemokine C-C motif ligand 18 (CCL18/PARC), surfactant protein D (SP-D), lipopolysaccharide (LPS)-binding protein, and soluble cluster of differentiation 14 (sCD14) were measured using enzyme-linked immunosorbent assays, and LPS levels were measured using a Limulus amebocyte lysate assay. Spirometry was also performed. Multivariable linear regression analysis was used to assess relationships of the blood biomarkers to lung function.

Results: Lung function impairment was independently associated with elevated plasma levels of CRP $(P<0.01)$, IL$6(P=0.04)$, IL-1 $\beta(P<0.01)$, and LBP $(P<0.01)$. Increasing age $(P<0.01)$, reduced body mass index $(P=0.02)$, prior hospitalizations $(P=0.03)$, and presence of Pseudomonas aeruginosa in sputum cultures $(P<0.01)$ were also associated with reduced lung function. Elevated concentrations of LPS in plasma were associated with a previous history of hospitalization $(P<0.05)$. There was a trend towards an increase in plasma IL-6 $(P=0.07)$ and IL-1 $\beta(P=$ $0.06)$ levels in patients who were previously hospitalized.
\end{abstract}

Conclusions: IL-6 and IL-1 $\beta$ are promising systemic biomarkers for lung function impairment and history of hospitalization in adult patients with CF.

\section{Background}

Cystic fibrosis (CF) is a progressive, debilitating disease that affects nearly 30,000 Americans and occurs with a frequency of about 1 in 3500 births [1]. It is characterized by persistent lung infection and lung function impairment. It also affects other organs including the sinuses, gastrointestinal tract, endocrine glands, and the bone [2-5]. Although all CF cases are caused by a mutation in the gene for the CF transmembrane conductance regulator, there is considerable heterogeneity in the rate at which the disease progresses [6]. The traditional risk factors for rapid progression include reduced body mass

\footnotetext{
* Correspondence: pman@providencehealth.bc.ca

UBC James Hogg Research Centre, Institute for Heart + Lung Health at St. Paul's Hospital and Department of Medicine, University of British Columbia, Vancouver, BC, Canada
}

(c) 2012 Ngan et al; licensee BioMed Central Ltd. This is an Open Access article distributed under the terms of the Creative Commons Attribution License (http://creativecommons.org/licenses/by/2.0), which permits unrestricted use, distribution, and reproduction in any medium, provided the original work is properly cited. index, colonization of the airways with pathogenic bacteria such as Pseudomonas aeruginosa, and female sex [7-9]. More recently, some have suggested that systemic inflammation may be another important risk factor for poor health outcomes in CF independent of these traditional risk factors $[3,8,10,11]$. However, the studies that have evaluated this issue have produced inconsistent results and have measured different components of the immune system, making cross comparisons difficult. Moreover, none of these studies have evaluated these biomarkers on hard clinical outcomes such as exacerbations or hospitalizations, which are important endpoints in CF. In this study, we determined the relationship of plasma inflammatory biomarkers to lung function and hospitalization history in adult patients with CF. The plasma biomarkers were carefully chosen to represent 
innate or adaptive immunity, a by-product of Gramnegative pathogens, or lung-based proteins.

\section{Methods \\ Study Population and Blood Collection}

We enrolled 58 consecutive adult patients from the Cystic Fibrosis (CF) Clinic at St. Paul's Hospital (Vancouver, British Columbia, Canada) between April and December 2009, who were clinically stable at the time of assessment. For inclusion, patients had to have one or more clinical features consistent with the CF phenotype [12] as well as a genotype with two identifiable disease-causing CF transmembrane conductance regulator (CFTR) mutations and sweat chloride measurements greater than $60 \mathrm{mmol} / \mathrm{L}$ on two occasions. Patients who had an exacerbation within the previous 4 weeks were excluded from the study. This study was conducted with the approval of the University of British Columbia - Providence Health Care Research Ethics Board (UBC-PHC REB). Following informed consent, we collected venous blood samples and performed spirometry using standard techniques, in accordance with guidelines from the American Thoracic Society [13]. Demographic and clinical data were obtained by chart review.

\section{Clinical Information}

The subjects' infection status was determined by microbial review within the preceding 3 years of study entry. Those who had at least one sputum culture positive of Pseudomonas aeruginosa were considered to be infected by this organism. We also performed chart review and retrieved data from the hospital database to determine whether the patients had a hospitalization for CF exacerbation in the previous 5 years.

\section{Biomarker Assays}

Plasma was prepared from the collected blood samples and a select number of circulating inflammatory proteins were measured using high-sensitivity enzymelinked immunosorbent assay (ELISA) kits that were commercially available. These included interleukin (IL)6 and IL-1 $\beta$ (R\&D Systems, Minneapolis, MN), cytokines involved in the early phase inflammatory response; C-reactive protein (CRP; R\&D Systems), an acute phase response protein; granzyme B (GzmB; eBioscience, San Diego, $C A)$, a protein involved in adaptive immunity; chemokine $\mathrm{C}-\mathrm{C}$ motif ligand 18/pulmonary and activation-regulated chemokine (CCL18/PARC; R\&D Systems) and surfactant protein D (SP-D; Biovendor, Brno, Czech Republic), pneumo-proteins (i.e. proteins synthesized predominantly in the lungs) $[14,15]$; and LPS-binding protein (LBP; Hycult Biotech, Uden, The Netherlands) and soluble cluster of differentiation 14 (sCD14; R\&D Systems), proteins involved in lipopolysaccharide (LPS) signalling. The coefficients of variation for these kits were $7.4 \%, 12.3 \%, 3.1 \%, 5.8 \%, 1.2 \%, 2.2 \%, 1.7 \%$, and $5.9 \%$ respectively, and the lower detection limits were 0.039 $\mathrm{pg} / \mathrm{mL}, 0.057 \mathrm{pg} / \mathrm{mL}, 0.010 \mathrm{ng} / \mathrm{mL}, 0.2 \mathrm{pg} / \mathrm{mL}, 0.01 \mathrm{ng} /$ $\mathrm{mL}$, and $0.2 \mathrm{ng} / \mathrm{mL}, 4.4 \mathrm{ng} / \mathrm{mL}$, and $0.125 \mathrm{ng} / \mathrm{mL}$ respectively. LPS levels were measured using a commercially-available kinetic chromogenic Limulus amebocyte lysate (LAL) assay kit (Lonza Walkersville, Walkersville, MD) following plasma dilution and heat inactivation pre-treatment steps to diminish interference from plasma proteins. The coefficient of variation for the assay was $2.2 \%$, and the lower detection limit was 0.5 $\mathrm{pg} / \mathrm{mL}$. Of these biomarker assays, only the IL-1 $\beta$ ELISA had samples with values below the limit of detection (18 undetectable out of 58 samples, or $31 \%$ ). In plasma samples, the manufacturers' reported ranges for IL- 6 , IL- $1 \beta$, CRP, GzmB, and sCD14 measurements in healthy volunteers were 0.428 to $8.8 \mathrm{pg} / \mathrm{mL}$, non-detectable to $0.452 \mathrm{pg} / \mathrm{mL}, 104$ to $4185 \mathrm{ng} / \mathrm{mL}, 0.8$ to $24.1 \mathrm{pg} / \mathrm{mL}$, and 1200 to $3100 \mathrm{ng} / \mathrm{mL}$, respectively. Reference ranges were not available for CCL18/PARC, SP-D, LBP, and LPS, and the dynamic ranges of these assays were 7.8 to $500 \mathrm{pg} / \mathrm{mL}, 1.56$ to $100 \mathrm{ng} / \mathrm{mL}, 4.4$ to $50 \mathrm{ng} / \mathrm{mL}$, and 0.5 to $500 \mathrm{pg} / \mathrm{mL}$, respectively.

\section{Statistical Analysis}

Data for the biomarker measurements were analyzed after natural log transformation due to their skewed distribution, and values below the limit of detection were assigned the value of the lower detection limit for the particular kit. The relationships of the biomarkers to lung function $\left(\mathrm{FEV}_{1}\right.$ as a percentage of predicted) and to each other were assessed using linear regression. Multivariable linear regression analysis was performed to assess the role of possible confounding factors such as age, sex, and pseudomonal status. Plasma biomarker levels were compared between those who did and did not experience a hospitalization in the past using a Student's $t$-test for independent samples. Fisher's exact test was used to analyze categorical data. The independent relationship of plasma biomarkers to $\mathrm{FEV}_{1 \%}$ predicted was ascertained using multiple regression analysis. To ensure parsimony and enhance the robustness of the model, we used a stepwise approach to select only those covariates that significantly impacted on the relationship (the significance level for entering, $P \leq 0.05$ and the significance level for stay, $P \leq 0.05$ ). To facilitate interpretation and cross-comparisons of beta-coefficients of plasma biomarkers from the regression model, we standardized the beta-coefficients to their standard deviation. Thus, the beta-coefficients are presented per $1 \mathrm{SD}$ increase in the plasma biomarker expression. $P$-values less than 0.05 were considered significant (two-tailed test). All 
analyses were conducted using SAS (Carey, N.C.) version 9.1.

\section{Results \\ Patient Demographics}

The age of the study subjects ranged from 18 to 61 years (Table 1). The baseline clinical characteristics of the study subjects are summarized in Table 1 in two groups based on the median value of $\mathrm{FEV}_{1 \%}$ predicted. Greater mean age, reduced BMI, hospitalizations in the previous 5 years, and presence of Pseudomonas aeruginosa in sputum cultures were all significantly associated with below-median $\mathrm{FEV}_{1 \%}$ predicted values. Of the 58 subjects, 21 had been hospitalized ( $36 \%$ of total) and 37 had not. 42 of the subjects were classified as Pseudomonas + based on sputum microbiology (72.41\% of total) and 16 were Pseudomonas-. A greater portion of patients with below-median $\mathrm{FEV}_{1 \%}$ predicted values had been administered Azithromycin and Tobramycin versus patients with above-median $\mathrm{FEV}_{1 \%}$ predicted values.

\section{Systemic Inflammation and Lung Function}

CRP, IL-6, IL-1 $\beta$, and LBP were significantly correlated with lung function impairment in both univariable and multivariable analysis (Table 2). LPS was significantly related to $\mathrm{FEV}_{1}$ only in the multivariable analysis. The use of standardized beta-coefficient (i.e. the change in $\mathrm{FEV}_{1} \%$ predicted per 1 standard deviation increase in the plasma concentrations of the biomarker) allows for comparison of the beta-coefficients across biomarkers. CRP had the highest standardized beta-coefficient, followed by LBP, IL- 6 and IL- $1 \beta$, suggesting that CRP is most strongly associated with $\mathrm{FEV}_{1}$. Geometric mean plasma levels of IL- 6 , IL- $1 \beta$, CRP, and LBP of patients with below-median $\mathrm{FEV}_{1 \%}$ predicted values were $3.0 \mathrm{pg} /$ $\mathrm{mL}, 0.21 \mathrm{pg} / \mathrm{mL}, 4.6 \mu \mathrm{g} / \mathrm{mL}$, and $33.2 \mu \mathrm{g} / \mathrm{mL}$, respectively. These were all significantly higher than in patients with above-median $\mathrm{FEV}_{1 \%}$ predicted values (1.6 $\mathrm{pg} / \mathrm{mL}, 0.12 \mathrm{pg} / \mathrm{mL}, 2.0 \mu \mathrm{g} / \mathrm{mL}$, and $22.9 \mu \mathrm{g} / \mathrm{mL}$, respectively) (Figure 1). The geometric mean plasma level of GzmB was significantly lower in patients with belowmedian $\mathrm{FEV}_{1 \%}$ predicted values $(71.6 \mathrm{pg} / \mathrm{mL})$ compared to those with above-median $\mathrm{FEV}_{1 \%}$ predicted values (166.3 pg/mL).

\section{Circulating Systemic Inflammatory Biomarkers and Hospitalization History}

The geometric mean plasma levels of IL-6, IL-1 $\beta$, and LPS of hospitalized CF subjects were $3.6 \mathrm{pg} / \mathrm{mL}, 0.19$ $\mathrm{pg} / \mathrm{mL}$, and $1.3 \mathrm{ng} / \mathrm{mL}$, respectively. These were all significantly higher than in non-hospitalized subjects (1.7 $\mathrm{pg} / \mathrm{mL}, 0.10 \mathrm{pg} / \mathrm{mL}$, and $0.97 \mathrm{ng} / \mathrm{mL}$, respectively) (Table 3). After adjustment for $\mathrm{FEV}_{1 \%}$ predicted, BMI and pseudomonal status in sputum, the relationships weakened (Table 3). There was a significant association between plasma IL-6 levels and IL-1 $\beta$ levels (Figure 2). Geometric mean plasma concentrations of CRP, GzmB, CCL18, SP-D, LBP, and SCD14 did not significantly differ between the previously hospitalized and non-hospitalized groups (Table 3). The c-statistic of $\mathrm{FEV}_{1}$, BMI and pseudomonal status together was 0.797 . There was a modest improvement in the c-statistic by adding IL-6, IL-1 $\beta$, or LPS (0.837, 0.828 , and 0.841 , respectively).

Table 1 Patient demographics and clinical characteristics

\begin{tabular}{|c|c|c|c|c|}
\hline & $\begin{array}{l}\text { Total } \\
(\mathrm{n}=58)\end{array}$ & $\begin{array}{l}\mathrm{FEV}_{1 \%} \text { predicted } \\
\geq \text { median } \\
(\mathrm{n}=29)\end{array}$ & $\begin{array}{l}\mathrm{FEV}_{1 \%} \text { predicted } \\
<\text { median } \\
(\mathrm{n}=29)\end{array}$ & $P$-value \\
\hline Age, years range & $18-61$ & $18-49$ & $19-61$ & $<0.01$ \\
\hline Sex, male n (\%) & $34(58.62)$ & $18(62.1)$ & $16(55.2)$ & 0.79 \\
\hline $\mathrm{BMI}, \mathrm{kg} / \mathrm{m}^{2} \pm \mathrm{SD}$ & $23.24 \pm 3.25$ & $24.2 \pm 3.4$ & $22.3 \pm 2.9$ & 0.02 \\
\hline $\mathrm{FEV}_{1}, \%$ predicted $\pm \mathrm{SD}$ & $71.93 \pm 24.80$ & $92.9 \pm 12.9$ & $51.0 \pm 13.2$ & - \\
\hline \multicolumn{5}{|l|}{ Current medications } \\
\hline Azithromycin, n (\%) & $18(31.03)$ & $3(10.3)$ & $15(51.7)$ & $<0.01$ \\
\hline Ciprofloxacin, n (\%) & $2(3.45)$ & $1(3.4)$ & $1(3.4)$ & 1.00 \\
\hline Dornase alfa, n (\%) & $24(41.38)$ & $11(37.9)$ & $13(44.8)$ & 0.79 \\
\hline Ibuprofen, n (\%) & $2(3.45)$ & $2(6.9)$ & $0(0)$ & 0.49 \\
\hline Prednisone, n (\%) & $0(0)$ & $0(0)$ & $0(0)$ & - \\
\hline Tobramycin, n (\%) & $13(22.41)$ & $2(6.9)$ & $11(37.9)$ & 0.01 \\
\hline Inhaled steroids, n (\%) & $37(63.79)$ & $15(51.7)$ & $22(75.9)$ & 0.10 \\
\hline Diabetes, n (\%) & $22(37.93)$ & $10(34.5)$ & $12(41.4)$ & 0.79 \\
\hline Hospitalization, n (\%) & $21(36.2)$ & $6(20.7)$ & $15(51.7)$ & 0.03 \\
\hline Pseudomonas, n (\%) & $42(72.41)$ & $15(51.7)$ & $27(93.1)$ & $<0.01$ \\
\hline
\end{tabular}


Table 2 Relationship between FEV $_{1}$ percent predicted and biomarkers in CF subjects per 1 log increase in the biomarkers $(n=58)$

\begin{tabular}{lccccc}
\hline & Unadjusted & & Adjusted* & & $\begin{array}{c}\text { Standardized Beta-Coefficient } \\
\text { (per 1 SD increase in the levels of biomarker) }\end{array}$ \\
\hline Biomarker & $\boldsymbol{\beta} \pm \mathrm{SE}$ & $\boldsymbol{P}$-value & $\boldsymbol{\beta} \pm \mathrm{SE}$ & $\boldsymbol{P}$-value & \\
\hline $\mathrm{CRP}, \mathrm{mg} / \mathrm{L}$ & $-10.61 \pm 2.65$ & $<0.01$ & $-7.04 \pm 1.98$ & $<0.01$ & -0.3134 \\
$\mathrm{IL}-6, \mathrm{pg} / \mathrm{mL}$ & $-10.72 \pm 3.11$ & $<0.01$ & $-5.53 \pm 2.66$ & 0.04 & -0.2159 \\
$\mathrm{IL}-1 \beta, \mathrm{pg} / \mathrm{mL}$ & $-6.97 \pm 3.36$ & 0.04 & $-4.65 \pm 2.67$ & $<0.01$ & -0.1784 \\
$\mathrm{SP}-\mathrm{D}, \mu \mathrm{g} / \mathrm{mL}$ & $-17.70 \pm 7.95$ & 0.03 & $-9.83 \pm 5.93$ & 0.10 & -0.1584 \\
$\mathrm{CCL} 18, \mathrm{pg} / \mathrm{mL}$ & $-6.33 \pm 5.93$ & 0.29 & $-3.01 \pm 4.23$ & 0.48 & -0.0672 \\
$\mathrm{Gz} \mathrm{mB}, \mathrm{pg} / \mathrm{mL}$ & $4.09 \pm 2.27$ & 0.08 & $-0.33 \pm 1.89$ & 0.86 & -0.0187 \\
$\mathrm{LPS}, \mathrm{pg} / \mathrm{mL}$ & $1.07 \pm 7.44$ & 0.89 & $13.30 \pm 5.41$ & 0.02 & 0.0239 \\
$\mathrm{SCD} 14, \mu \mathrm{g} / \mathrm{mL}$ & $1.88 \pm 9.67$ & 0.85 & $-10.26 \pm 6.96$ & 0.15 & -0.1414 \\
$\mathrm{LBP}, \mu \mathrm{g} / \mathrm{mL}$ & $-22.28 \pm 6.63$ & $<0.01$ & $-16.02 \pm 4.74$ & $<0.01$ & -0.2946 \\
\hline
\end{tabular}

* Adjusted for age, pseudomonal status, and history of hospitalization, which were significantly related to reduced lung function

\section{Discussion}

This was a unique study investigating the relationship of systemic inflammation to lung function impairment and hospitalization history among clinically stable CF patients. This study produced several important findings. First, biomarkers that are related to innate immunity or early acute phase reactants such as IL-6, IL-1 $\beta$, CRP, and LBP were significantly associated with reduced lung function in CF patients independent of age, pseudomonal status, or history of hospitalization, suggesting that systemic inflammation is an independent risk factor for disease progression in CF. The directionality of the relationship is uncertain. Thus, it remains unknown whether the rise in these biomarkers is the result or the cause of impaired lung function. Our data extend the findings of a previous study that examined a cohort of adult CF patients aged 30 years or greater. Levy et al. found an association between lower $\mathrm{FEV}_{1}$ percent predicted and higher serum CRP levels, but they did not adjust for sex or pseudomonal status of the patients, and the study cohort was limited to an older population [11]. Furthermore, their retrospective study design prevented them from obtaining serum samples and performing pulmonary function tests within a close proximity of time. While our current study did not make comparisons to healthy controls, previous studies have found that median plasma or serum concentrations of IL-6, IL-1 $\beta$, IL-1 receptor antagonist (IRAP) [16], neutrophil granule proteins, and CRP [17] were higher in CF patients versus healthy subjects. Collectively, the use of plasma markers of systemic inflammation, especially IL- 6 and CRP, provides additional indicators of clinical status and may add to our understanding of the relationship between inflammation and the severity of lung disease in CF patients.

Second, in addition to the traditional factors such as reduced BMI, poor lung function as measured by $\mathrm{FEV}_{1}$ percent predicted, and presence of Pseudomonas aeruginosa in sputum cultures, we found that plasma levels of two early phase inflammatory cytokines, IL-6 and IL-1 $\beta$, were significantly associated with prior hospitalization in patients with $\mathrm{CF}$, independent of the traditional factors. However, there was no significant relationship of GzmB, a marker of adaptive immunity, lung-based proteins such as CCL18/PARC and SP-D, or acute-phase reactants such as CRP, LBP, and SCD14 [18] with hospitalization history. Together, these data suggest that early phase inflammatory cytokines may be good candidate plasma biomarkers of health outcomes in CF.

Our third important finding was that plasma LPS derived from Gram-negative bacteria is significantly higher in those who were previously hospitalized for a CF exacerbation than those who were not. LPS is an immunologically active antigen, which can cause an intense inflammatory process in the lung and elsewhere. Its presence in the systemic circulation may enhance the systemic inflammatory response in CF, as previously seen in a murine model [19]. We postulate that some of the LPS expression in the systemic circulation may be derived from the lungs through a process called translocation. It is conceivable that the diseased respiratory tract in CF may facilitate translocation of bacterial components or pro-inflammatory cytokines from the lungs to the systemic circulation where it incites an inflammatory response. This biological plausibility is supported by a study in rabbits where it was shown that it is physically possible for LPS to undergo pulmonary-to-systemic translocation under certain conditions, specifically in mechanical ventilation strategies [20]. While our methods did not allow us to determine the originating source of plasma LPS, we speculate that the LPS we measured is likely derived from $P$. aeruginosa in the lungs or other Gram-negative, CF-related bacteria. Future studies will be needed to test this hypothesis. 


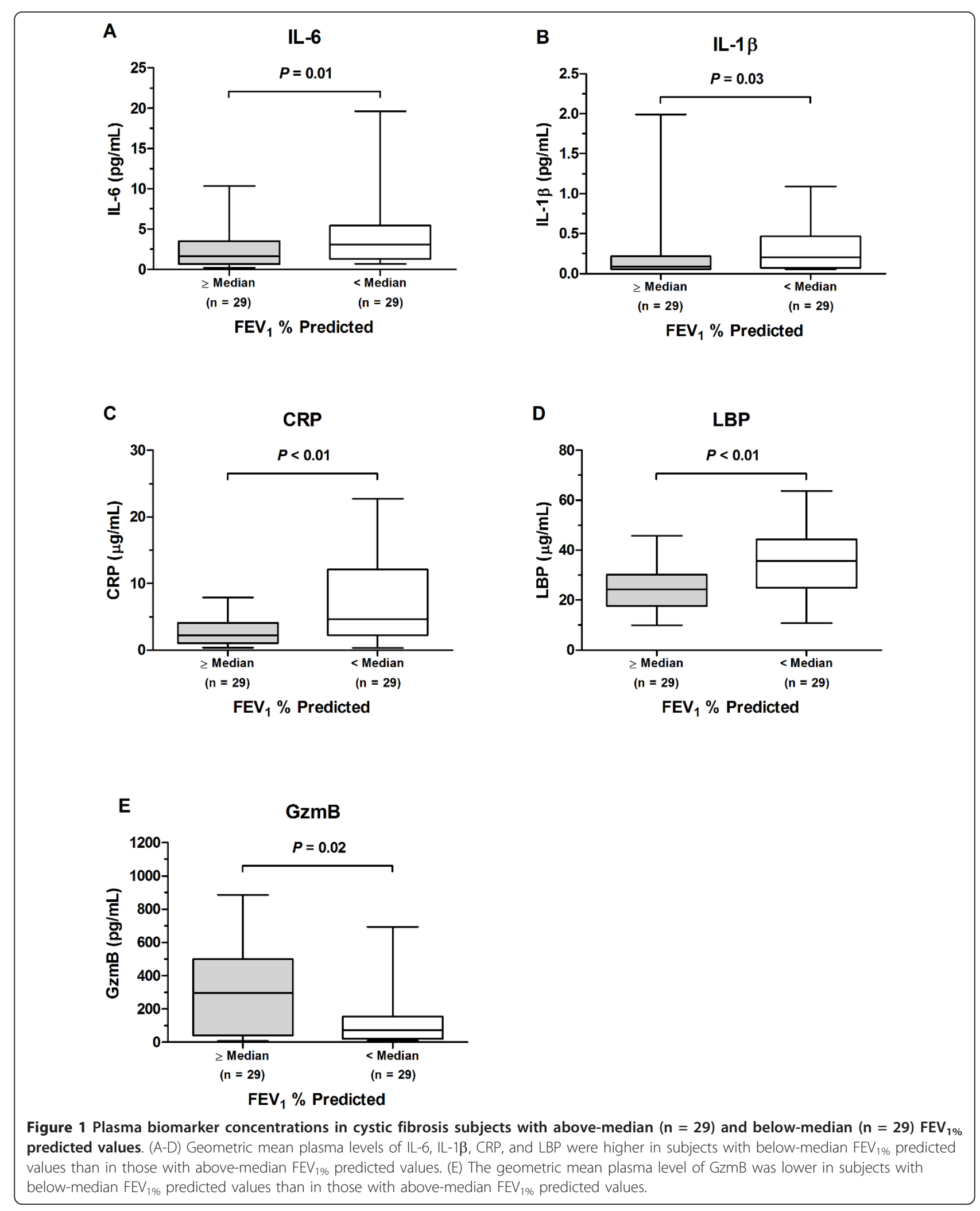


Table 3 Geometric means (and interquartile ranges) of biomarkers in CF patients who were and were not previously hospitalized

\begin{tabular}{|c|c|c|c|c|c|c|}
\hline Biomarker & $\begin{array}{c}\text { Total } \\
(\mathrm{n}=58)^{*}\end{array}$ & $\begin{array}{l}\text { Previously hospitalized } \\
(\mathrm{n}=21)^{*}\end{array}$ & $\begin{array}{l}\text { Not previously hospitalized } \\
(\mathrm{n}=37)^{*}\end{array}$ & $P$-value & Adjusted $P$-value ${ }^{\dagger}$ & c-statistics \\
\hline $\mathrm{CRP}, \mu \mathrm{g} / \mathrm{mL}$ & $\begin{array}{c}3.0 \\
(1.5,6.1)\end{array}$ & $\begin{array}{c}3.5 \\
(2.0,8.0)\end{array}$ & $\begin{array}{c}2.8 \\
(1.3,5.6)\end{array}$ & 0.50 & 0.51 & 0.795 \\
\hline$\| \mathrm{L}-6, \mathrm{pg} / \mathrm{mL}$ & $\begin{array}{c}2.2 \\
(1.1,4.2)\end{array}$ & $\begin{array}{c}3.6 \\
(2.8,5.8)\end{array}$ & $\begin{array}{c}1.7 \\
(1.0,3.1)\end{array}$ & $<0.01$ & 0.07 & 0.837 \\
\hline $\mathrm{IL}-1 \beta, \mathrm{pg} / \mathrm{mL}$ & $\begin{array}{c}0.16 \\
(0.06,0.29)\end{array}$ & $\begin{array}{c}0.19 \\
(0.06,0.50)\end{array}$ & $\begin{array}{c}0.10 \\
(0.06,0.20)\end{array}$ & $<0.01$ & 0.06 & 0.828 \\
\hline $\mathrm{SP}-\mathrm{D}, \mathrm{ng} / \mathrm{mL}$ & $\begin{array}{c}84.3 \\
(64.0,112.3)\end{array}$ & $\begin{array}{c}87.5 \\
(75.3,106.1)\end{array}$ & $\begin{array}{c}82.6 \\
(63.7,113.2)\end{array}$ & 0.60 & 0.26 & 0.804 \\
\hline $\mathrm{CCL} 18, \mathrm{ng} / \mathrm{mL}$ & $\begin{array}{c}59.5 \\
(41.4,75.3)\end{array}$ & $\begin{array}{c}60.1 \\
(38.7,73.5)\end{array}$ & $\begin{array}{c}59.2 \\
(44.5,75.9)\end{array}$ & 0.92 & 0.92 & 0.797 \\
\hline GzmB, pg/ml & $\begin{array}{c}109.2 \\
(25.5,389.8)\end{array}$ & $\begin{array}{c}90.7 \\
(25.4,384.9)\end{array}$ & $\begin{array}{c}121.2 \\
(26.2,389.8)\end{array}$ & 0.46 & 0.83 & 0.792 \\
\hline LPS, ng/mL & $\begin{array}{c}1.1 \\
(0.9,1.3)\end{array}$ & $\begin{array}{c}1.3 \\
(1.0,1.4)\end{array}$ & $\begin{array}{c}1.0 \\
(0.8,1.3)\end{array}$ & 0.01 & 0.04 & 0.841 \\
\hline $\mathrm{sCD} 14, \mu \mathrm{g} / \mathrm{mL}$ & $\begin{array}{c}1.1 \\
(0.9,1.3)\end{array}$ & $\begin{array}{c}1.1 \\
(1.0,1.3)\end{array}$ & $\begin{array}{c}1.1 \\
(0.8,1.3)\end{array}$ & 0.89 & 0.49 & 0.789 \\
\hline $\mathrm{LBP}, \mu \mathrm{g} / \mathrm{mL}$ & $\begin{array}{c}27.6 \\
(22.0,39.9)\end{array}$ & $\begin{array}{c}30.8 \\
(23.7,41.2)\end{array}$ & $\begin{array}{c}25.9 \\
(18.8,35.7)\end{array}$ & 0.17 & 0.79 & 0.781 \\
\hline
\end{tabular}

* Data are presented as geometric mean $\left(25^{\text {th }}, 75^{\text {th }}\right.$ percentile)

${ }^{+}$Adjusted for FEV ${ }_{1 \%}$ predicted, BMI, and pseudomonal status, which collectively had a c-statistic (or area under the curve) value of 0.797

There were important limitations to our study. This is a cross-sectional study, which precludes firm conclusions on causality or directionality of the relationship. While we postulate that systemic inflammation drives disease progression, it is entirely possible that disease progression is responsible for systemic inflammation, and a comprehensive prospective longitudinal study would be needed to address this issue. Longitudinal data may also provide insight into plasma biomarker profiles during acute exacerbations and following antibiotic treatment. Additionally, we did not measure other proinflammatory biomarkers such as TNF- $\alpha$ and IL- 8 or

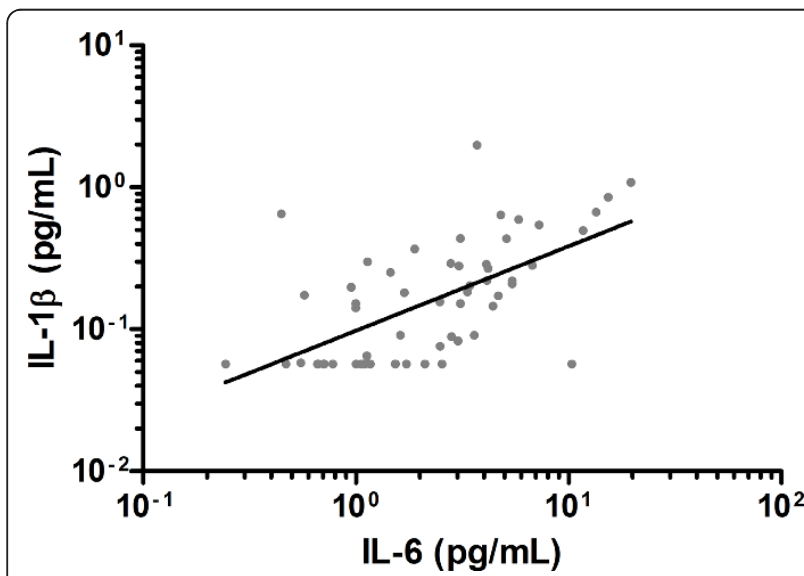

Figure 2 Plasma IL- 6 was significantly correlated with plasma IL-1 $\beta$ in cystic fibrosis subjects $(\boldsymbol{n}=\mathbf{5 8}) . \beta \pm \mathrm{SE}=0.595 \pm 0.105$; IL-6 and IL-1 $\beta$ In-transformed. $R^{2}=0.37 ; P<0.01$. those with known anti-inflammatory effects such as IL10 , which has been shown in a mouse model to reduce the inflammatory response to Pseudomonas aeruginosa [21]. Future investigation into these regulators of the inflammatory response could provide a clearer picture of the complex interactions involved that lead from excessive inflammation to disease progression.

\section{Conclusions}

Notwithstanding the limitations, we found that more intense systemic inflammation, mediated by the innate immune system, is associated with prior CF hospitalizations and with lung function impairment in CF. IL-6 and IL-1 $\beta$, in particular, are promising systemic biomarkers for disease progression and hospitalization in CF. A large prospective study testing these promising biomarkers would be of great value in determining their usefulness as a clinical tool in managing patients with CF.

\section{Acknowledgements}

The authors acknowledge the assistance of Cystic Fibrosis Clinic study coordinators Vincent Zenarosa and Wen Wang for recruitment of subjects in this study as well as for blood collection. This work is supported by the Canadian Institutes of Health Research.

\section{Authors' contributions}

DAN carried out the immunoassays, contributed to the acquisition and interpretation of the data, performed statistical analysis, and drafted the manuscript for important intellectual content; PGW participated in the design of the study and contributed to the acquisition and interpretation of the data; MA contributed to the acquisition and interpretation of the data; $Y L$ contributed to the acquisition of the data; JAL participated in the design of the study and contributed to the acquisition and interpretation of the data; DDS participated in the design of the study, performed statistical 
analysis, contributed to interpretation of the data, and drafted the manuscript for important intellectual content; SFPM conceived the study, participated in the design of the study, contributed to interpretation of the data, and drafted the manuscript for important intellectual content. All authors read and approved the final manuscript.

\section{Competing interests}

The authors declare that they have no competing interests.

Received: 30 May 2011 Accepted: 14 February 2012

Published: 14 February 2012

\section{References}

1. Cystic Fibrosis Foundation: Cystic Fibrosis Foundation Patient Registry: 2009 Annual Data Report. Bethesda, MD; 2011.

2. Shead EF, Haworth CS, Barker H, Bilton D, Compston JE: Osteoclast function, bone turnover and inflammatory cytokines during infective exacerbations of cystic fibrosis. J Cyst Fibros 2010, 9(2):93-98.

3. Elborn JS: How can we prevent multisystem complications of cystic fibrosis? Semin Respir Crit Care Med 2007, 28(3):303-311.

4. Haworth CS, Selby PL, Webb AK, Martin L, Elborn JS, Sharples LD, Adams JE: Inflammatory related changes in bone mineral content in adults with cystic fibrosis. Thorax 2004, 59(7):613-617.

5. Ionescu AA, Nixon LS, Evans WD, Stone MD, Lewis-Jenkins V, Chatham K, Shale DJ: Bone density, body composition, and inflammatory status in cystic fibrosis. Am J Respir Crit Care Med 2000, 162(3 Pt 1):789-794.

6. Konstan MW, Wagener JS, VanDevanter DR: Characterizing aggressiveness and predicting future progression of CF lung disease. J Cyst Fibros 2009, 8(Suppl 1):S15-9.

7. Nick JA, Chacon CS, Brayshaw SJ, Jones MC, Barboa CM, St Clair CG, Young RL, Nichols DP, Janssen JS, Huitt GA, Iseman MD, Daley CL, TaylorCousar JL, Accurso FJ, Saavedra MT, Sontag MK: Effects of gender and age at diagnosis on disease progression in long-term survivors of cystic fibrosis. Am J Respir Crit Care Med 2010, 182(5):614-626.

8. Downey DG, Martin SL, Dempster M, Moore JE, Keogan MT, Starcher B, Edgar J, Bilton D, Elborn JS: The relationship of clinical and inflammatory markers to outcome in stable patients with cystic fibrosis. Pediatr Pulmonol 2007, 42(3):216-220.

9. Kerem E, Corey M, Gold R, Levison H: Pulmonary function and clinical course in patients with cystic fibrosis after pulmonary colonization with Pseudomonas aeruginosa. J Pediatr 1990, 116(5):714-719.

10. Olesen HV, Holmskov U, Schiotz PO, Sorensen GL: Serum-surfactant SP-D correlates inversely to lung function in cystic fibrosis. J Cyst Fibros 2010, 9(4):257-262.

11. Levy H, Kalish LA, Huntington I, Weller N, Gerard C, Silverman EK, Celedon JC, Pier GB, Weiss ST: Inflammatory markers of lung disease in adult patients with cystic fibrosis. Pediatr Pulmonol 2007, 42(3):256-262.

12. Rosenstein BJ, Cutting GR: The diagnosis of cystic fibrosis: a consensus statement. Cystic Fibrosis Foundation Consensus Panel. J Pediatr 1998, 132(4):589-595.

13. American Thoracic Society: Standardization of spirometry-1987 update. Statement of the American Thoracic Society. Am Rev Respir Dis 1987, 136(5):1285-1298.

14. Hieshima K, Imai T, Baba M, Shoudai K, Ishizuka K, Nakagawa T, Tsuruta J, Takeya M, Sakaki Y, Takatsuki K, Miura R, Opdenakker G, Van Damme J, Yoshie O, Nomiyama H: A novel human CC chemokine PARC that is most homologous to macrophage-inflammatory protein-1 alpha/LD78 alpha and chemotactic for T lymphocytes, but not for monocytes. J Immunol 1997, 159(3):1140-1149.

15. Persson A, Chang D, Rust K, Moxley M, Longmore W, Crouch E: Purification and biochemical characterization of CP4 (SP-D), a collagenous surfactant-associated protein. Biochemistry 1989, 28(15):6361-6367.

16. Kronborg G, Hansen MB, Svenson M, Fomsgaard A, Hoiby N, Bendtzen K: Cytokines in sputum and serum from patients with cystic fibrosis and chronic Pseudomonas aeruginosa infection as markers of destructive inflammation in the lungs. Pediatr Pulmonol 1993, 15(5):292-297.

17. Rayner RJ, Wiseman MS, Cordon SM, Norman D, Hiller EJ, Shale DJ: Inflammatory markers in cystic fibrosis. Respir Med 1991, 85(2):139-145

18. Bas S, Gauthier BR, Spenato U, Stingelin S, Gabay C: CD14 is an acutephase protein. J Immunol 2004, 172(7):4470-4479.
19. Tamagawa E, Suda K, Wei Y, Xing L, Mui T, Li Y, van Eeden SF, Man SF, Sin DD: Endotoxin-induced translocation of interleukin- 6 from lungs to the systemic circulation. Innate Immun 2009, 15(4):251-258.

20. Murphy DB, Cregg N, Tremblay L, Engelberts D, Laffey JG, Slutsky AS, Romaschin A, Kavanagh BP: Adverse ventilatory strategy causes pulmonary-to-systemic translocation of endotoxin. Am J Respir Crit Care Med 2000, 162(1):27-33.

21. Chmiel JF, Konstan MW, Knesebeck JE, Hilliard JB, Bonfield TL, Dawson DV, Berger M: IL-10 attenuates excessive inflammation in chronic Pseudomonas infection in mice. Am J Respir Crit Care Med 1999, 160(6):2040-2047.

\section{Pre-publication history}

The pre-publication history for this paper can be accessed here: http://www.biomedcentral.com/1471-2466/12/3/prepub

doi:10.1186/1471-2466-12-3

Cite this article as: Ngan et al:: The relationship of systemic inflammation to prior hospitalization in adult patients with cystic fibrosis. BMC Pulmonary Medicine 2012 12:3.

\section{Submit your next manuscript to BioMed Central and take full advantage of:}

- Convenient online submission

- Thorough peer review

- No space constraints or color figure charges

- Immediate publication on acceptance

- Inclusion in PubMed, CAS, Scopus and Google Scholar

- Research which is freely available for redistribution

Submit your manuscript at www.biomedcentral.com/submit
Biomed Central 